\title{
Assessment of Land Use/Cover Change Using Remote Sensing and GIS Techniques: A Case of Osogbo and Its Peripheral Areas in Nigeria
}

\author{
${ }^{* 1}$ AFOLABI, OS; ${ }^{2}$ AIGBOKHAN, OJ; ${ }^{2}$ MEPHORS, JO; ${ }^{2}$ OLOKETUYI, AJ \\ ${ }^{1}$ Remote Sensing and GIS Laboratory,Department of Environmental Modelling \& Biometrics, ${ }^{2}$ Department of Forest crop production, \\ Forest Research Institute of Nigeria, P.M.B 5054 \\ Ibadan, Nigeria \\ *Corresponding Author Email: mosadioluwaolamidipupo@gmail.com
}

\begin{abstract}
The importance of accurate and timely information describing the nature and extent of land resources and changes over time is increasing, especially in rapidly growing city areas. Landsat satellite imageries of three different time periods, i.e., Landsat Thematic Mapper (TM) of 1982, 2000 and 2018 were acquired by Global Land Cover Facility Site (GLCF) and earth explorer site, quantify the changes in the Osogbo and its peripheral areas from 1982 to 2018 over a period of 36 years. These data sets were imported in ArcGIS 10.3, ERDAS Imagine and IDRIS Selva, satellite image processing softwares to create a false colour composite (FCC), supervised classification methodology was employed using maximum likelihood technique. The images of the study area were categorized into four different classes namely Core-urban, Peri-urban, Vegetation, water body. The results indicate that during the last thirty-six (36) years, Core-Urban land and water body have been increased by $2.74 \%(38.20 \mathrm{~km} 2)$ and $0.98 \%(13.69$ $\mathrm{km} 2)$ while Peri-Urban land, and vegetation cover have decreased by $0.35 \%(5.00 \mathrm{~km} 2)$, and $3.36 \%(46.87 \mathrm{~km} 2)$, respectively. The results quantify the land cover change patterns in the city and its peripheral area and demonstrate the potential of multitemporal Landsat data to provide an accurate, economical means to map and analyse changes in land cover over time that can be used as inputs to land management and policy decisions.
\end{abstract}

\section{DOI: $\underline{\text { https://dx.doi.org/10.4314/jasem.v25i4.8 }}$}

Copyright: Copyright $\odot 2021$ Afolabi et al. This is an open access article distributed under the Creative Commons Attribution License (CCL), which permits unrestricted use, distribution, and reproduction in any medium, provided the original work is properly cited.

Dates: Received: 14February 2021; Revised: 26 March 2021; Accepted: 12 April 2021

Keywords: Remote sensing, land cover, land change, landsat thematic mapper

Land use/cover is two separate terminologies which are often used interchangeably (Dimyati et al., 1996). Land over refers to the physical characteristics of earth's surface, captured in the distribution of vegetation, water, soil and other physical features of the land, including those created solely by human activities e.g., settlements. While land-use refers to the way in which land has been used by humans and their habitat, usually with accent on the functional role of land for economic activities. The land use/cover pattern of a region is an outcome of natural and socioeconomic factors and their utilization by man in time and space. Information on land use/cover and possibilities for their optimal use is essential for the selection, planning and implementation of land use schemes to meet the increasing demands for basic human needs and welfare. This information also assists in monitoring the dynamics of land use resulting out of changing demands of increasing population. Land use affects land cover and changes in land cover affect land use. Changes in land cover by land use do not necessarily imply degradation of the land. However, many shifting land use patterns driven by a variety of social causes, result in land cover changes that affects biodiversity, water and radiation budgets, trace gas emissions and other processes that come together to affect climate and biosphere (Riebsame et al., 1994). Land use/cover change detection is very essential for better understanding of landscape dynamic during a known period of time having sustainable management. Land use/cover changes is a widespread and accelerating process, mainly driven by natural phenomena and anthropogenic activities, which in turn drive changes that would impact natural ecosystem (Ruiz-Luna and Berlanga-Robles, 2003; Turner and Ruscher, 2004). Understanding landscape patterns, changes and interactions between human activities and natural phenomenon are essential for proper land management and decision improvement. Today, earth resource satellites data are very applicable and useful for land use/cover change detection studies (Yuan et al., 2005; Brondizio et al., 1994). With the invent of remote sensing and Geographical Information System (GIS) techniques, land use/cover mapping has given a useful and detailed way to improve the selection of areas designed to agricultural, urban and/or industrial areas of a region (Selcuk et al., 2003). Application of 
remotely sensed data made possible to study the changes in land cover in less time, at low cost and with better accuracy (Kachhwala, 1985) in association with GIS that provides suitable platform for data analysis, update and retrieval (Chilar, 2000). The advent of high spatial resolution satellite imagery and more advanced image processing and GIS technologies, has resulted in a switch to more routine and consistent monitoring and modelling of land use/land cover patterns. Remote-sensing has been widely used in updating land use/cover maps and land use/cover mapping has become one of the most important applications of remote sensing (Lo and Choi, 2004). Landsat-TM images represent valuable and continuous records of the earth's surface during the last 3 decades (USGS, 2014). Moreover, the entire Landsat archive is now available free-of-charge to the scientific public, which represents a wealth of information for identifying and monitoring changes in manmade and physical environments (Chander et al., 2009; El Bastawesy, 2014). Several studies acknowledged the importance of pre-processing (i.e., data selection, co-registration, radiometric calibration and normalization) in performing accurate and reliable change detection analysis (Jensen, 2005; Lu et al., 2004; Mas, 1999; Scheidt et al., 2008; El Bastawesy et al., 2013). Some research scholars have made extensive research on land use/land cover change detection using remotely sensed images. Daniel et al. (2002) have compared land use/ land cover change detection methods and made use of 5 methods, viz., traditional postclassification cross tabulation, cross correlation analysis, neural networks, knowledge-based expert systems and image segmentation and object-oriented classification. They observed that there are merits to each of the five methods examined and that, at the point of their research, no single approach can solve the land use change detection problem. Yuan et al. (2005)developed a methodology to map and monitor land cover change using multi-temporal Landsat TM data in the seven-county Twin Cities Metropolitan Area of Minnesota for 1986, 1991, 1998 and 2002. Their result showed that between 1986 and 2002 the amount of urban land increased from $23.7 \%$ to $32.8 \%$ of the total area, while rural cover types of agriculture, forest and wetland decreased from $69.6 \%$ to $60.5 \%$. Adepoju et al. (2006) examined the land use/land cover changes that have taken place in Lagos for the last two decades due to the rapid urbanisation. A postclassification approach was adopted by Adepoju with a maximum likelihood classifier algorithm. El Gammal et al. (2010) have used several Landsat images of different time periods (1972, 1982, 1987, 2000, 2003 and 2008) and processed these images in ERDAS and ARC-GIS software to analyse the changes in the shores of the lake and in its water volume. Bhagawat (2011) presented the change analysis based on the statistics extracted from the four land use/land cover maps of the Kathmandu Metropolitan by using GIS. According to him, land use statistics and transition matrices are important information to analyse the changes of land use. ElAsmar et al. (2013)have applied remote sensing indices, i.e., normalized difference water index (NDWI) and the modified normalized difference water index (MNDWI) in the Burullus Lagoon, North of the Nile Delta, Egypt for quantifying the change in the water body area of the lagoon during 1973 to 2011 .

However, Nigeria has been regarded as the most populous nation in Africa with a teaming population of over 130 million crowded over a land area of about 923,000 square kilometers. It has over a hundred cities with population that passes for urban centres. Nigerian cities Notably Lagos, Kano and Ibadan are among the first one hundred largest cities in the world (World Gazetteer, 2005), which translates into pressures on land and thus high urban dynamics. The pressures on land orchestrated by increased rate of urbanization brought with it intractable urban problems, such as poor environmental sanitation, pollution, crime, unemployment and overcrowding among others. Many writers confirmed that Nigerian urban centres are faced with rapid growth and development, which contribute to land use change. Though land use changes are indirect consequence of national economic growth, it is important to evaluate land use changes in the regional and the local context in order to assist in anticipating the impacts associated with change and contribute to an understanding of productive environmental sustainability (Laymon, 2003). Therefore, an attempt is made in this study to map out the status of land use/cover of Osogbo and its peripheral being at traditional city, in view to detect the land consumption rate and the changes that has taken place over the last 36 years with a view to project what may obtainable by year 2036 using geospatial techniques.

Study area: Osogbo is the capital city of Osun State, one of the thirty six states in Nigeria. It is located on latitude $7.7^{\circ} \mathrm{N}$ and longitude $4.5^{\circ} \mathrm{E}$ of Greenwich meridian with an average height of about $300 \mathrm{~m}$ above the sea level. It was founded in the late $18^{\text {th }}$ century and originated as a traditional as well as cultural town which derives its name from the proclamation by the goddess of Osun River. The town is known for very rich arts and cultural heritage (Adenike, and Akinola, 1991; Awe and Albert, 1995). Following the creation of Osun State in 1991, Osogbo assumed the status of a state capital. It has two local government areas, which are consisting of Osogbo and Olorunda with 
surrounding local governments which are Egbedore, Ede North and South respectively. The population of Osogbo according to the 1991 census before it became a state capital was 189,733 and its total land area is about 2,875sq, km. (Afolabi, 2001). Over the years, Osogbo has witnessed tremendous growth, both spatially and in population. The establishment of a railway station is perhaps a major factor in the growth of Osogbo. Apart from the railway, postal and telecommunication, PHCN (now Ibadan Electricity Distribution Company) regional station, road network, agglomeration of heavy and many light industries, being the seat of government and the presence a good number of higher institutions, Osogbo thus became a major trading and distribution centre for people within and outside its immediate environment.In recent times, the location of Osogbo as a state capital, coupled with other factors mentioned above, has led to the influx of people from other towns and villages, thus giving it the status of a twin city, that is, a traditional as well as a modern city (Adenike and Akintola, 1991) and this account for the uncoordinated expansion of the city into its fringes which has posed serious consequences on land use planning and management. Below is the map showing the study area.

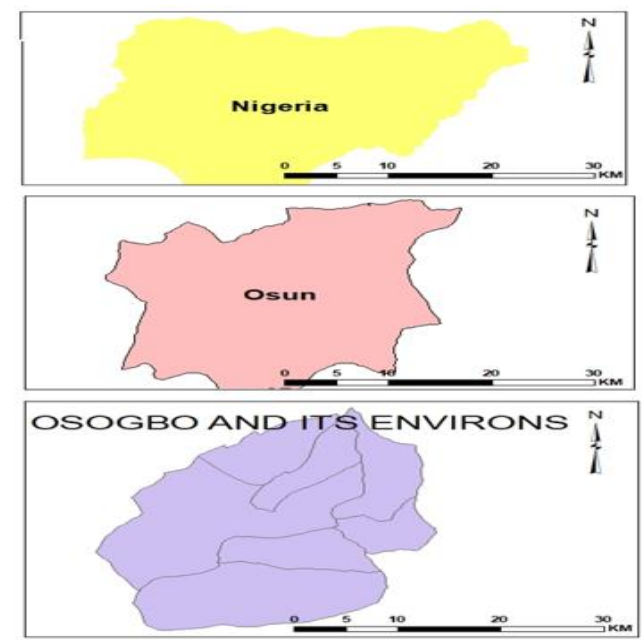

Fig 1: Map of Osun State showing the Seven Local Government Areas under study as Osogbo and its peripheral.

\section{MATERIAL AND METHODS}

Database preparation: Three data sets of Landsat Thematic Mapper at a resolution of 30m of 1982, 2000 and 2018 were used for land use/cover classification. The satellite data covering study area were obtained from global land cover facility (GLCF) http://glcfapp.glcf.umd.edu:8080/esdi/) and earth explorer site (http://earthexplorer.usgs.gov/). These data sets were imported in ArcGIS 10.3,ERDAS Imagine and IDRIS Selva, satellite image processing softwares to create a false colour composite (FCC). The layer stack option in image interpreter tool box was used to generate FCCs for the study areas. The sub-setting of satellite images were performed for extracting study area from both images by taking georeferenced out line boundary of Osogbo and its peripheral map as AOI (Area of Interest). For better classification results some indices such as normalized difference vegetation index (NDVI), normalized difference water index (NDWI) and normalized difference builtup index (NDBI) were also created to classify the Landsat images.

Land use/cover detection and analysis: To work out the land use/cover classification, supervised classification method with maximum likelihood algorithm was applied. The Maximum Likelihood algorithm assumes that the histograms of the bands of data have normal distributions. If this is not the case, you may have better results with the Parallelepiped or Minimum Distance Decision Rule, or by performing a first-pass Parallelepiped Classification. The Maximum Likelihood Decision rule is based on the probability that a pixel belongs to a particular class. It calculates the probability of a pixel being in a certain class and assigns it to the class with the highest probability.

\section{RESULTS AND DISCUSSIONS}

The results obtained through the analysis of multitemporal satellite imageries were diagrammatically illustrated in Figs. 2-4and data are registered in Tables 1, 2 and 3 respectively. Fig. 2depicts spatial distributional pattern of land use/cover of Osogbo and its peripheral for the year 1982 while Fig. 3 for the year 2000 and Fig 4 show 2018. These data reveals that in 1982 , about $74.78 \%(1040.89 \mathrm{~km} 2)$ area of Osogbo and its peripheral was under vegetation, $21.35 \%$ (297.21 km2) under peri-Urban, $3.74 \%$ (52.03 km2) under Core-Urban/ built_up Area, and 0.12\% (1.68 $\mathrm{km} 2$ ) under water body. While in 2000 land categories was found about $79.17 \%(1101.90 \mathrm{~km} 2)$ under vegetation, $30.17 \%(204.84 \mathrm{~km} 2)$ under Peri-Urban land, $5.31 \%(73.84 \mathrm{~km} 2)$ under Core-Urban/ built-up Area, and $0.81 \%(11.23 \mathrm{~km} 2)$ under water body. However, 2018 the area under these land categories was found about $71.42 \% \quad(994.02 \mathrm{~km} 2)$ under vegetation, $20.99 \%(292.12 \mathrm{~km} 2)$ under Peri-Urban land, $6.48 \%(90.23 \mathrm{~km} 2)$ under Core-Urban/built up area, and $1.104 \%$ (15.37 km2) under water body. For the projected LULC of Osogbo and its peripheral in the year 2036 as projected about $61.24 \%$ (850.49 $\mathrm{km} 2)$ under vegetation, $27.13 \%(375.83 \mathrm{~km} 2)$ under Peri-Urban land, $9.68 \%(132.96 \mathrm{~km} 2)$ under CoreUrban/ built-up Area, and $1.94 \%(32.53 \mathrm{~km} 2)$ under water body. 


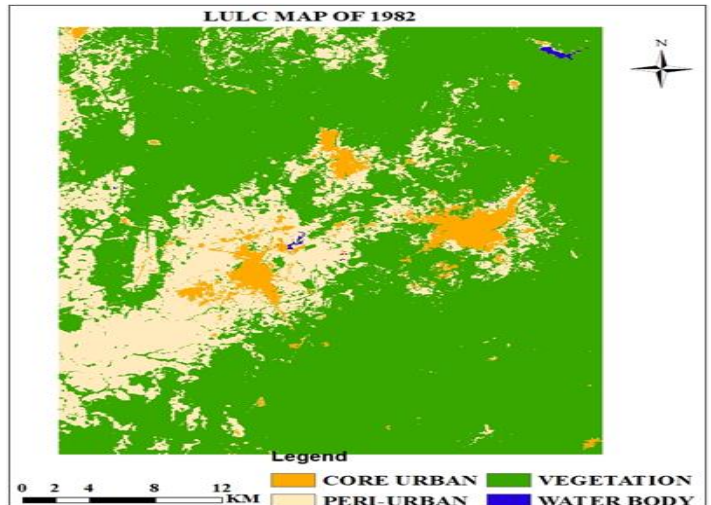

Fig 2: Land use land covers classification 1982

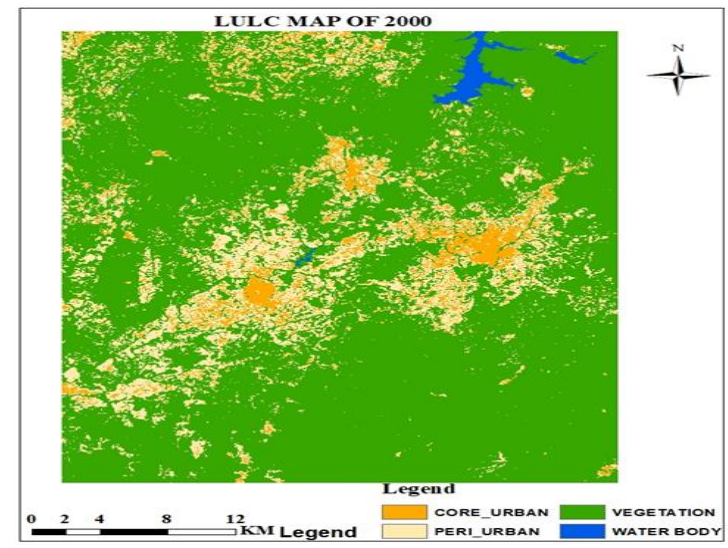

Fig 3: Land use land covers classification 2000

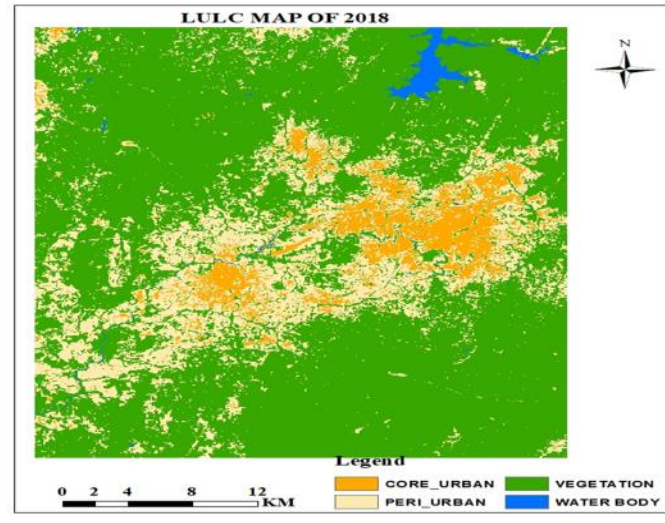

Fig 4: Land use land covers classification 2018

Table 1: Showing the area covered by different land use classes in Osogbo and its peripheral region during the year 1982

\begin{tabular}{lll}
\hline Land use / land cover classes & $\mathbf{K M}^{\mathbf{2}}$ & $\mathbf{\%}$ \\
\hline Core-Urban & 52.0326 & 3.73848 \\
Peri-Urban & 297.2052 & 21.35386 \\
Vegetation & 1040.8950 & 74.78713 \\
Water Body & 1.6776 & 0.12053 \\
Total & $\mathbf{1 3 9 1 . 8 1 0 4}$ & $\mathbf{1 0 0}$ \\
\hline
\end{tabular}

Table 2: Showing the area covered by different land use classes in Osogbo and its peripheral region during the year 2000

\begin{tabular}{lll}
\hline Land use / land cover classes & $\mathbf{K M}^{2}$ & $\%$ \\
\hline Core-Urban & 73.8414 & 5.30542 \\
Reri-Urban & 204.8424 & 14.71772 \\
Vegetation & 1101.8961 & 79.16999 \\
Water Body & 11.2302 & 0.80688 \\
Total & 1391.8104 & $\mathbf{1 0 0}$ \\
\hline
\end{tabular}

Table 3: Showing the land use/land cover of the study area during the three observing years

\begin{tabular}{lllllll}
\hline $\mathbf{1 9 8 2}$ & \multicolumn{2000}{c}{} & $\mathbf{2 0 1 8}$ & \\
\hline $\mathbf{K m}^{2}$ & $\%$ & $\mathbf{K m}^{2}$ & $\%$ & $\mathbf{K m}^{2}$ & $\%$ & Core-Urban \\
\hline 52.0326 & 3.73848 & 73.8414 & 5.30542 & 90.2295 & 6.48289 & \\
297.2052 & 21.35386 & 204.8424 & 14.71772 & 292.1976 & 20.99407 & Peri Urban \\
1040.8950 & 74.78713 & 1101.8961 & 79.16999 & 994.0167 & 71.41897 & Vegetation \\
1.6776 & 0.12053 & 11.2302 & 0.80688 & 15.3666 & 1.10407 & Water Body \\
1391.8104 & 100 & 1391.8104 & 100 & 1391.8104 & 100 & Total \\
\hline
\end{tabular}

Land use/cover change: Data registered in Table 3reveal that both increase and decrease changes occurred in the land use/cover pattern of Osogbo and its peripheral. During the last thirty six years the vegetation in the study area has increased from $1040.8950 \mathrm{~km} 2$ in 1982 to $1101.8961 \mathrm{~km} 2$ in 2000 which accounts for $4.38 \%$ increase, while 2018 there was a decrease $994.0167 \mathrm{~km} 2$ which amount to $7.75 \%$ decrease of the total study area this implies that desertification and deforestation processes may have occur during this period. Which means largely embodies the thinning out of the vegetation, decrease or destruction of perennial grass, and an increase and spreading of undesirable bush and woody species. The overall vegetation change has been ordinated into five broadly overlapping phases. These are primary degradation, denudation, revegetation, secondary degradation and a desertified phase.

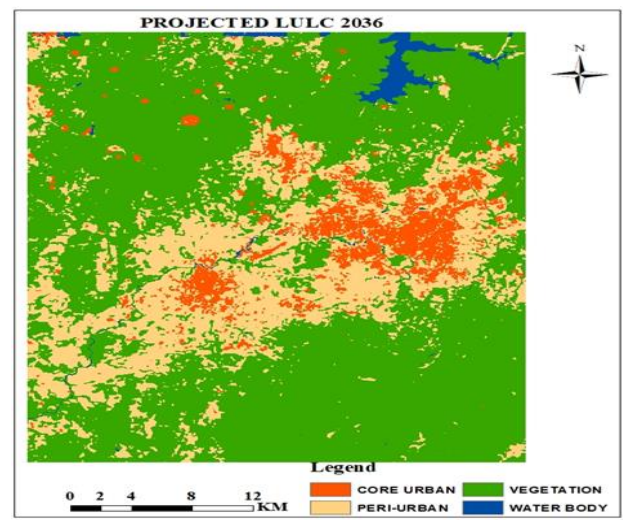

Fig 5: Land use land covers classification 2036 
Table 3: Showing the projected land use/land cover of the study area by year 2036

\begin{tabular}{lll}
\hline $\mathbf{2 0 3 6}$ & & \\
\cline { 1 - 2 } $\mathbf{K m}^{2}$ & $\%$ & Core-Urban \\
& 9.68312 & Peri Urban \\
375.8256 & 27.13276 & Vegetation \\
850.4937 & 61.24701 & Water Body \\
32.5296 & 1.94820 & Total \\
1391.8104 & 100 & \\
\hline
\end{tabular}

The peri-urban has decreased from $297.2052 \mathrm{~km} 2$ in 1982 to $204.8424 \mathrm{~km} 2$ in 2000 which accounts for $6.63 \%$ while in 2018 it was $292.1976 \mathrm{~km} 2$ which is an $6.27 \%$ increase compared with year 2000 result. The core-urban area has increased from $52.0326 \mathrm{~km} 2$ in 1982 to $73.8414 \mathrm{~km} 2$ in 2000 which accounts for $3.55 \%$ and year 2018 it also increases to $90.2295 \mathrm{~km} 2$ which amount to $1.17 \%$ increase. This maybe as a result of urbanization which account for population agglomeration and steady development over time. The water body of the study area has slightly increased from $1.6776 \mathrm{~km} 2$ in 1982 to $11.2302 \mathrm{~km} 2$ in 2000 which accounts for $0.68 \%$, while 2018 was 15.3666 $\mathrm{km} 2$ which accounts for $0.29 \%$ increase.

Conclusion: The change pattern and temporal process in Osogbo and its environs does not conform to the popular land use theories; it comprises of urban core, surrounded by the high, medium and low-density areas. It is also obvious that the city is growing at such an alarming rate using up all the green and other forms of soft landscape in the city. Thus, the present study illustrates that remote sensing and GIS are important technologies for temporal analysis and quantification of spatial phenomena which is otherwise not possible to attempt through conventional mapping techniques.

\section{REFERENCES}

Adenike, B; Akinola, J (1991). The Built Environment: Innovation Policy and Sustainable Development. Proceeding of International Conference Organised by Covenant University, Sango-Otta, pp.17-21.

Adepoju, MO; Millington, AC, Tansey, KT (2006). Land Use/ Land Cover Change Detection in Metropolitan Lagos (Nigeria): 1984-2002, American Society for Photogrammetry and Remote Sensing, Annual Conference, Reno, Nevada, May 1-5.

Afolabi, O (2001): Geographical Analysis of Land Uses in Osogbo, A paper presented at a workshop in Department of Geography and Planning Science, University of Ado-Ekiti. March 2001.
Awe, J; Albert, B (1995): Changes in land use and land cover: A global perception USA: Cambridge University Press.

Bauer, ME; Sersland, C. A; Steinberg, S. J (1996). Land cover classification of the Twin Cities metropolitan area with Landsat TM data. Proceedings, Pecora 13 symposium. August 2022, Sioux Falls, South Dakota (pp. 138-145).

Bhagawat, R (2011). Application of remote sensing and GIS, land use/land cover change in Kathmandu metropolitan city. Nepal J. Theory. Appl. Inform. Technol. 23 (2), 80-86.

Brondizio, E.S; Moran, E.F; Wu, Y (1994). Land use change in the Amazon estuary: patterns of Caboclo settlement and landscape management. Hum. Ecol. 22 (3), 249-278.

Chander, G; Markham, B.L; Helder, D.L (2009). Summary of current radiometric calibration coefficients for Landsat MSS, TM, ETM+, and EO-1 ALI sensors. Rem. Sen. Environ. 113 (5). 893-903.

Chilar, J (2000). Land cover mapping of large areas from satellites: status and research priorities. Inter. J. Rem. Sen. 21, 1093-1114.

Daniel, L. C.; James, D. H.; Emily, H. W.;Mingjun, S.; Zhenkui, Z (2002). A Comparison of Land use and Land cover Change Detection Methods, ASPRS-ACSM Annual Conference and FIG 22nd Congress, p. 2.

Dimyati, M.; Mizuno, K.;Kitamura, T (1996). An analysis of landuse/cover change using the combination of MSS Landsat and land use map: a case study in Yogyakarta, Indonesia. Inter. J. Rem. Sen.17, 931-944.

Environmental Protection Agency. (2003). The urban environment. Minneapolis- St. Paul indicators. http://www.epa.gov/urban/msp/indicators.htm. (website last visited August 5, 2005).

Ewijk, K. (2002). Analysis of landscape changes in the Twin Cities metropolitan area from 1986 to 1998 using Landsat TM classifications and landscape metrics. MGIS capstone paper. Minneapolis, Minnesota' University of Minnesota, $150 \mathrm{pp}$.

El-Asmar, H.M.; Hereher, M.E.; El Kafrawy, S.B (2013). Surface area change detection of the Burullus Lagoon, North of the Nile delta, Egypt, 
using water indices: a remote sensing approach. Egypt. J. Rem. Sens. Space Sci. 16, 119-123.

El Bastawesy, M.; Ramadan Ali, R.; Faid, A.; El Osta, M (2013). Assessment of water logging in agricultural megaprojects in the closed drainage basins of the Western Desert of Egypt. J. Hydro. Earth Sys. Sci. 17, 1493-1501

El Gammal, E.A.; Salem, S.M.; El Gammal, A.E.A (2010). Change detection studies on the world's biggest artificial lake (Lake Nasser, Egypt). Egypt. J. Rem. Sens. Space Sci. 13, 89-99.

Elvidge, C. D.;Sutton, P. C.; Wagner, T. W. et al. (2004). Urbanization. In G. Gutman, A. Janetos, Justice C., et al., (Eds.), Land change science: Observing, monitoring, and understanding trajectories of change on the earth's surface ( $p p$. 315- 328). Dordrecht, Netherlands' Kluwer Academic Publishers.

Fabiyi, O (2004). Gated Neighbourhoods and Privatisation of urban security in Ibadan metropolis. Occasional publication No 16 IFRA. Ibadan 2004.

Jensen, J.R.; (2005). Digital change detection. Introductory Digital Image Processing, A Remote Sensing perspective. Pearson Prentice Hall, New York, pp. 467-494.

Kachhwala, T.S (1985). Temporal monitoring of forest land for change detection and forest cover mapping through satellite remote sensing. In: Proceedings of the 6th Asian Conference on Remote Sensing. National Remote Sensing Agency, Hyderabad, pp. 77-83.

Mabogunje, A. (1995). The Environmental Challenges in Sub-Saharan Africa. Environment pg.1-11

Mas, J.F (1999). Monitoring land-cover changes: a comparison of change detection techniques. Inter. J. Rem. Sen. 20 (1), 139-152

Ngombe O.; Mike B.; Sarah Turner (2006). Sustaining the Unsustainable? City and Society in Indonesia", in Third World Planning Review. 2. 20

Lanjouw, A.; Levy, O (2002). Urban Growth Resources Proceedings of the Resources for tomorrow conference. 3, queen's printer, Ottawa, pp. 191- 195.
Lo C.P.; Choi, J.; (2004). A hybrid approach to urban land use/cover mapping using Landsat 7 enhanced thematic mapper plus (ETM+) images. Inter. J. Rem. Sen. 25 (14), 2687-2700

Lu, D.; Mausel, P.; Brondizio, E.; Moran, E (2004). Change detection techniques. Inter. J. Rem. Sen. 25 (12), 2365-2407.

O. FabiyiOluseyi, (2006).Urban Land Use Change Analysis of a Traditional City from Remote Sensing Data: The Case of Ibadan Metropolitan Area. Nig. Hum. Soc. Sci. J. 1 (1): 42-64

Riebsame, W.E.; Meyer, W.B.; Turner, B.L (1994). Modeling land-use and cover as part of global environmental change. Climate Change 28, 4564.

Ruiz-Luna. A; Berlanga-Robles C.A (2003). Land use, land cover changes and costal lagoon surface reduction associated with urban growth in northwest Mexico. Land. Ecol. 18, 159-171.

Selcuk, R.; Nisanci, R.; Uzun, B.; Yalcin, A.; Inan, H.; Yomralioglu, T (2003). Monitoring land-use changes by GIS and remote sensing techniques: case study of Trabzon, http://www.fig.net/pub/

Tangiri W. (2006). Ecological Footprint and Appropriated Carrying Capacity: what Urban Economics leaves out. Environ. Urban. 2 (4) $37-$ 45

Turner, M.G.; Ruscher, C.L (2004). Change in landscape patterns in Georgia. USA Land. Ecol. 1 (4), 251-421.

Yuan, F; Sawaya, KE; Loeffelholz, B; Bauer, ME (2005a). Land cover classification and change analysis of the Twin Cities (Minnesota) Metropolitan Area by multi-temporal Landsat remote sensing. Rem. Sen. Envi. 98, 317-328.

Yuan, F; Bauer, ME; Heinert, NJ; Holden, G (2005). Multi-level land cover mapping of the Twin Cities (Minnesota) metropolitan area with multiseasonal Landsat TM/ETM+data. Geocarto International, 20(2), 5-14.

Yuan, D; Elvidge, CD; Lunetta, RS (1998). Survey of multispectral methods for land cover change analysis. Remote sensing change detection: Environmental monitoring methods and applications (pp. 21-39). Michigan' Ann Arbor Press. 